\section{Tettsomian a dectures}

ON

\section{MIDWIFERY AND DISEASES OF WOMEN.}

Delivered before the Medical Society of London.

$\mathrm{BI}$

C. H. F. ROUTH, M.D.,

Physician to the samakitan hospital for woMen AND CHILDREN.

\section{LeCture III. (Continued.)}

Tine Treatment of Fibrous Tumours.

Secondly, we have to consider the cases of fibrous tumour of the uterus for which gastrotomy was performed; and the whole uterus, tumour, or part of either, were removed. (See Table III.)

The cases to which I shall refer are thirty-three in number. The particulars of another, which I have heard of, I have not been able to obtain.

These cases consist of four of Dr. W. L. Atlee, one of Dr. T. L. Atlee, one of Mr. Heath of Manchester, one of Dr. Sloane, two of Mr. I. Baker Brown, one of Dr. Boyd, three of Dr. Clay, one of Dr. Granville, one of Dr. Parkman, one of Mr. Lane of London, two of Dr. Peaslee, three of Dr. Kimball, one of Dr. Burnham, one of Dr. Nelson, one of Dr. A. F. Sawyer, three of Mr. Spencer Wells, one of Mr. Fletcher, one of Dr. Hakes, one of Mr. Cadge, and three of Dr Kœberle. For notices and references to several of these, I am indebted to Mr. Clay's translation of Kiwisch on the Ovaries. To the same gentleman I am indebted for correcting some errors in some of his cases published by others. 'To Mr. I. B. Brown, to Mr. Wells, and to Mr. Cadge, I am indebted for the report of three other cases ; to the distinguished physician of Strasburg, Dr. Kœberle, for notices of his three cases; as well as for the reference to Dr. Kimball's cases, which he kindly gave me.

A resumé of these cases establishes the following conclusions.

Where these particulars are noted, nine were married, and only four single.

Where the age is given, in two it was between 20 and 25 ; in one, between 25 and 30 ; in four, between 30 and 35 ; in two, between 35 and 40 ; in seven, between 40 and 45 ; in three, between 45 and 50 ; in two, between 50 and 55 . One recovered between 20 and 25 ; one between 35 and 40 ; and two between 40 and 45. All the rest whose ages are given died.

The gross mortality of the entire thirty-three cases was twenty-three; the recoveries, ten.

As to the causes of death, nine died of hæmorrhage. In four of these cases, it was found that the hæmorrhage was due to the ligature having slipped after the operation, or being insufficiently tightened. In two other of the cases of death, the cause was probably excessive hæmorrhage during the operation. In most of these cases, it is also remarkable that it is not stated whether the pedicle left was transfixed, or the clamp used-a fact which may in some measure explain the loss of blood, the ligatures being insecure. Four patients are said to have died of peritonitis; two of gangrene of the intestines; one of pleuritis ; one of poisoning; one of pus in the veins; one of phlegmo- nous erysipelas of leg; one of inflammation brought on by a fall; and the rest of shock, between four to thirty-six hours after the operation.

'The study of these cases, however, admits of a more practical application when divided into three classes: 1. Extrauterine cases; 2. Parietal or intrauterine ; 3 . Cases where the uterus and ovaries were removed.

1. There were fifteen cases of extrauterine tumours extirpated. Five of these cases recovered, although one died three years afterwards of some obscure abdominal disease; three died of hæmorrhage; in two, owing to the slipping of the ligature-an accident which in our days could scarcely occur, with our improved means of securing cut surfaces; one died of shock; the remainder, of inflammatory complications. This gives an average mortality of 66 per cent. ; or, if we exclude the two hæmorrhage cases, where death arose because the ligatures employed were insufficient, of 61.4 per cent. But, in three more of the fatal cases, enucleation was performed-a proceeding which I believe is unwise, when made by gastrotony from the outer surface. It is precisely on the surface that we have the large vessels; and although, after a time, the uterus may contract till the enucleation is completed, they continue to bleed very freely. Again, as in contraction after pregnancy, the uterus partially relaxes again; secondary hæmorrhage may occur, and death follow. And here I may refer, as an argument against enucleation, to the effect produced by wounding a fibrous tumour through its uterine envelope by gastrotomy. Looking to some of the cases before given, it will be seen that, in two of these, the uterus was punctured externally in making the incision. In three others, it was purposely punctured by the trocar. In all but one-Mr. Hakes's fibrocystic case- the hæmorrhage was excessive from such openings. In the case I saw, the blood gushed out as from a pump. In two other cases, in one of which I saw a puncture made through the vaginal wall by a small exploratory needle, and in another which I myself punctured by a very small trocar, the hæmorrhage was also excessive, and could only be controlled by the actual cautery. 'This point is of practical importance in making exploratory punctures through the abdomen, and pointing out the great risk of enucleation or puncturing a solid tumour through the external coating of the uterus.

2. In the next class of cases, where the tumours were parietal, or partially intrauterine, involving the uterus itself, in some cases fibrocystic, the result is much more deplorable; and, out of nine extirpations of this kind, there were eight deaths, and only one recovery. Of the deaths, five were due to hamorrhage. Ilere, again, however, the cut surfaces were not well secured. In one, there was oozing from the cut surface; in two others, the ligature slipped. In four examples; again, only portions of the diseased mass were removed. This, for the reasons before said, would be a dangerous course. The low vitality of the cut tumour would necessarily lead to its gangrene, and, as a consequence, to the death of the patient. In one of these, we had death from pus in the veins at the post mortem examination; in another, erysipelatous inflammation of the leg; in the two others, death from hæmorrhage. In these last, enucleation was again practised after gastrotomy. Hence the death from hæmorrhage and shock. And it is remarkable, that the only case in this category that 
TABLE III.-Cases of Fibrous Tumours of the Uterus for which Gastrotomy was performed, and the Tumour or Uterus removed.

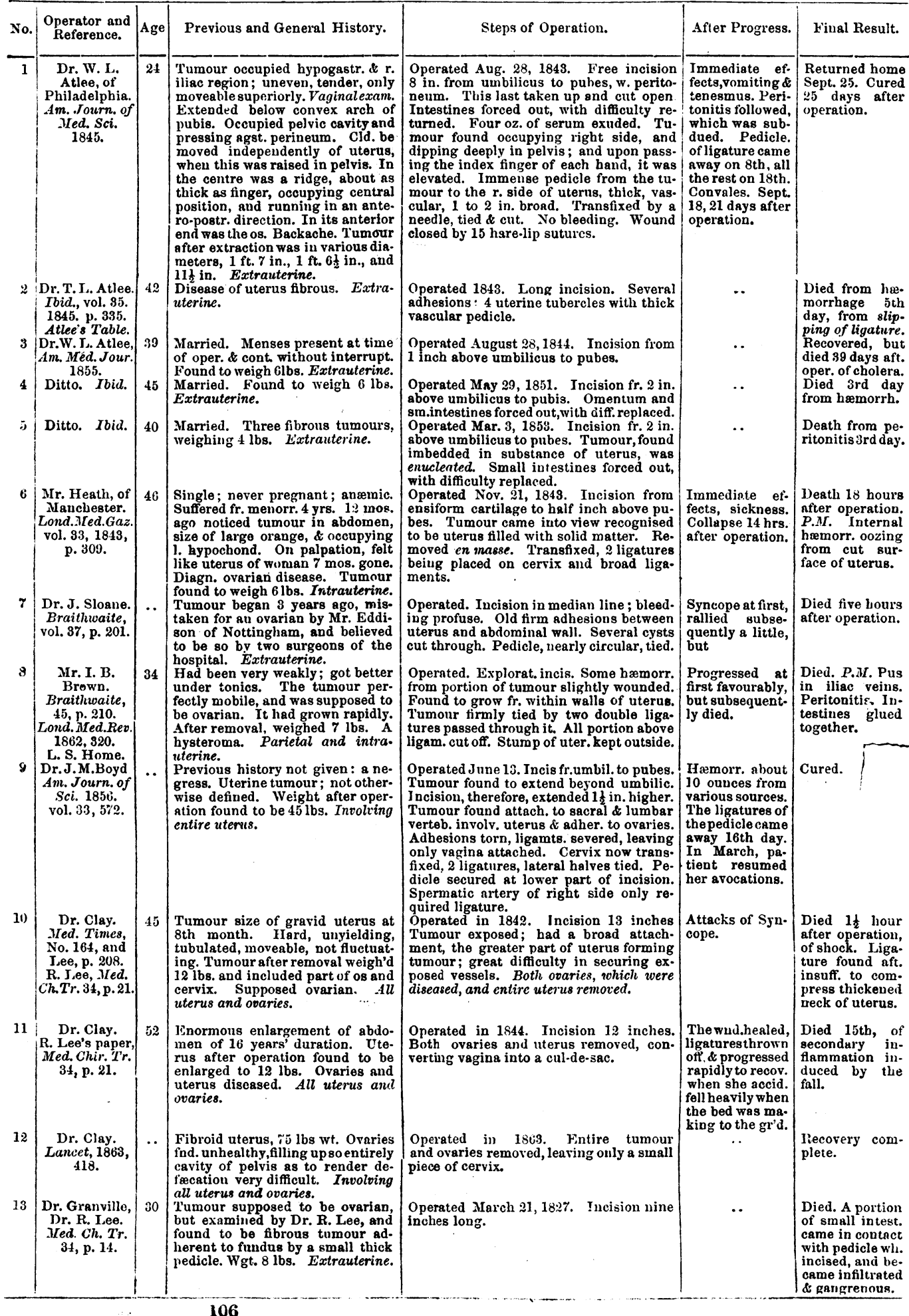


TABLE III-continued.

\begin{tabular}{|c|c|c|c|}
\hline No. & $\begin{array}{l}\text { Operator and } \\
\text { Referencc. }\end{array}$ & Age & Previjus and General History. \\
\hline 14 & $\begin{array}{l}\text { Dr. S. } \\
\text { Parkman. } \\
\text { America. } \\
\text { Lyman'sReport } \\
\text { Bost. 1856. }\end{array}$ & 27 & $\begin{array}{l}\text { Single. 'Tumour of oue yeur's du- } \\
\text { ration. Regular. Tapped, but no } \\
\text { fluid followed. Fibrous Tumour } \\
\text { of uterus. weight } 8 \text { lbs. 13 oz. } \\
\text { Parietal, involving entire Fundus. }\end{array}$ \\
\hline 15 & $\begin{array}{c}\text { Mr. Lane. } \\
\text { Lnndon. } \\
\text { Clay's Table, } \\
\text { Kivisch 'Trans. }\end{array}$ & 43 & $\begin{array}{l}\text { 'Twice married. No children. Dis- } \\
\text { ease of } 8 \text { or } 9 \text { years' duration. Cyst } \\
\text { spontaneously disappeared } 5 \text { suc- } \\
\text { cessive times, at intervals of about } \\
12 \text { to } 18 \text { months. For the last } 2 \\
\text { years before the operation, the } \\
\text { cyst did not give way, and she was } \\
3 \text { times tapped. Health good. } \\
\text { Extrauterine. Fibrocystic. }\end{array}$ \\
\hline 16 & $\begin{array}{l}\text { Dr. F. R. } \\
\text { Peaslee. } \\
\text { America. } \\
\text { Am. Journ. of } \\
\text { Med Sci. 1855, } \\
\text { p. } 393 .\end{array}$ & 35 & $\begin{array}{l}\text { Widow with } 4 \text { children. Tumour } \\
\text { in right iliac region noticed } 18 \\
\text { months previously. Leucorrhœa. } \\
\text { Dysuria. Numbness of the extrem. } \\
\text { Had pelvic inflammation after her } \\
\text { last child, } 17 \text { months back. Tum'r } \\
\text { moveable, falling into lower pelvis } \\
\text { when she is erect. Catheter ne- } \\
\text { cessary for several weeks. Sound } \\
\text { penetrated } 3 \frac{1}{2} \text { in. Cterus moveable } \\
\text { while the tumour is fixed. } \\
\text { Extranterine. }\end{array}$ \\
\hline $1 \%$ & $\begin{array}{c}\text { Dr. Kimball. } \\
\text { Bost..Yed.and } \\
\text { Surg.Journal, } \\
\text { 1855. }\end{array}$ & .. & $\begin{array}{l}\text { Anæmic. Unable to lay on her } \\
\text { back. Homorrhinge at the periods } \\
\text { fearful, likely to prove fatal. 'Tum'r } \\
\text { occupied centre of abdomen. Form } \\
\text { globular, laige; diameter probably } \\
7 \text { inches. Vaginal carmination: } \\
\text { Cervix normal. Sound penetrated } \\
4 \text { to } 5 \text { inches. Diseased mass was } \\
\text { so high up in ahdomen that could } \\
\text { not be felt per vaginam. Involving } \\
\text { all utcrus. }\end{array}$ \\
\hline 18 & $\begin{array}{l}\text { Dr. Kimball } \\
\text { Ibid. p. } 254 .\end{array}$ & .. & $\begin{array}{l}\text { Supposed ovarian. Jinormous ir- } \\
\text { regular and lobulated tum(sur, in- } \\
\text { volving uterus only. }\end{array}$ \\
\hline 19 & $\begin{array}{l}\text { Dr. Kimball. } \\
\text { Ibid. p. } 254 .\end{array}$ & .. & $\begin{array}{l}\text { Particulars not given. Fihrous } \\
\text { within walls of uterus. Parietal. }\end{array}$ \\
\hline 20 & $\begin{array}{l}\text { Dr. Walter } \\
\text { Burnham, of } \\
\text { r.owell. } \\
\text { Nelson's } \\
\text { Amer. Lancet, } \\
\text { Jau. 1854. }\end{array}$ & $\ldots$ & $\begin{array}{l}\text { Also copied in Worcester Medical } \\
\text { Journal, February løJt. }\end{array}$ \\
\hline 21 & $\begin{array}{l}\text { Dr. Nelson. } \\
\text { America. } \\
\text { Amer. Medical } \\
\text { Monthly, } \\
\text { 1859-60. } \\
\text { Bost. Med.and } \\
\text { Surg. Journ. } \\
1859 \cdot 60,507 .\end{array}$ & . & $\begin{array}{l}\text { Of } 5 \text { months standg., and consisted } \\
\text { of } 3 \text { lobes, of which largest filled } \\
\text { whole of left iliac region, and ext. } \\
\text { to the ribs and to the right of linea } \\
\text { alba, causing much distress by } \\
\text { compressing chest and stomach. } \\
\text { Diagnosed to be ovarian cyst. } \\
\text { Extrauterine. }\end{array}$ \\
\hline 2.) & $\begin{array}{l}\text { Dr. A. F. } \\
\text { Sawyer, of } \\
\text { San Francisco. } \\
\text { Am. Journ. of } \\
\text { Ied. Sciences, } \\
1860,+6 .\end{array}$ & 43 & $\begin{array}{l}\text { Mlarried, } 4 \text { children. Tumour first } \\
\text { noticed } 1849 \text {. In } 1855 \text { was of size } \\
\text { of two fists in centre of abdomen, } \\
\text { sinking when erect in pelvis. In } \\
\text { Oct. } 1856 \text {, confined of a healthy } \\
\text { child. After this, uterus could no } \\
\text { longer be felt, and tum'r resumed } \\
\text { its position in pelvis, which was } \\
\text { moveable. Parietal. }\end{array}$ \\
\hline 23 & $\begin{array}{l}\text { Mr. T.S. Wells, } \\
\text { of Loudon. } \\
\text { Communicated } \\
\text { and Operation } \\
\text { seen. }\end{array}$ & • & $\begin{array}{l}\text { Interstitial fibroid of uterus in } \\
\text { right uterine wall, of months' du- } \\
\text { ration. Severe menorrhagia. Ob- } \\
\text { scure fluctuation. Tumour exting. } \\
\text { above umbilicus. Weight found to } \\
\text { be } 17 \text { lbs. Parietal. }\end{array}$ \\
\hline 21 & $\begin{array}{c}\text { Ditto. } \\
\text { Communicated }\end{array}$ & & $\begin{array}{l}\text { Solid tibrous tumour of uterus, } \\
\text { weighing } 28 \text { ibs. }\end{array}$ \\
\hline 25 & $\begin{array}{c}\text { Ditto. } \\
\text { Path. Trans. } \\
\text { xiv, 201. }\end{array}$ & 53 & $\begin{array}{l}\text { Single. A case of fibrocystic pe- } \\
\text { dunculated ontgrowth. Right side } \\
\text { of fundus. Weight, if lbs. } 10 \% ; \\
\text { and a large cyst which had held } 26 \\
\text { pints of fluid, and } 4 \text { lbs. of lumpy } \\
\text { masses of decomposel tilline. } \\
\text { Fibrocystic. }\end{array}$ \\
\hline
\end{tabular}

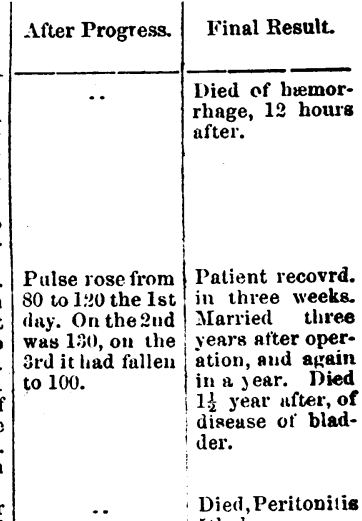

jth day.

Operated Sept 1853. Incis, 6 in. Trocar thrust in what appeared a dense sac tilled with fluid. Nothing but blood followed. Incision enlarged; turnour then found to proceed from uterus. Trocar puncture was bleeding ficely. Operat. c'ld not be suspen. Attempts to vomit, $\&$ intestines protruded. Incision extendel, \& lipature placed ar'nd uterus as soon as pos \& excised. Hom did a somor. dit not exceed $60 z$. Ligntures brongh at at lower angle of wound, by side of wh. gum elastic tube was left introduced. Wound united by 6 neelles carried thro the peritoneum.

Operated Sept.1. Incis. 1 in. thro' median Recovery some- liccovery comline upon projecting tumour. Atteinpt what retarded plete.

made to enucleate first, so as to remove by nauses and disersed mass, and thus make smaller vomiting, retenopenings. This was done with difhculty. tion of urine, Uterus then drawn out. Trunsfixed with etc. Couvalesct. double ligature at suppos. union w. cervix. quite in Jau. double ligature at suppos. union w. cervix. quite in Jau. Superior part then ampitated. Wound
brought together by 4 sutures. 4 oz. of
very long, not blood lost.

Whole diseased mass and organ removed. Lterus extirpated.

Uterus and both ovaries extirpated. awry till July. Farourable for, Died loth day. six days, th got $^{2}$ ill.

F'urourable for Died sid day, two days. from slipping of ligature.
Recovered in two montlis.

Two largest lobes removed hy the knife, leaving $x$ stump three inches in diameter.

gature came lecorered with away a few mos. out a bad syumpr. aft. without pa- Died is years aft. tient's knowi'ge, of obscure abd. Ibid. Jouvnal, disease, w. fistu$1858,29 \%$ lous opening in intestiue.

Operated under ether. Tncision from a Favourable up Died lith day. above umbil. to pubes. Was a large solid to 4 th day, when PM. Per.tonitis growth imbedded in parietes like an en- rigrors occurred, Sanguin'us fluid ormously hypertropar ure orm clots, 1002 rested on either side of tumnur, left ing. Pulse 140. Ligat. on stump healthy, right hypertrophied. Trunstixed of wound some\begin{tabular}{l|l} 
by a ligat. below cervix, all above removed. & what loosened
\end{tabular} \begin{tabular}{|l|l|} 
Ligatures left hanging out of wound. 'T'um'r & Death from se
\end{tabular} was calcareous, mixed up with fibroplastic ingredient, and inuscular aul cerebriform

\begin{tabular}{l|l|l|l} 
matter. & Collapse. Fe. & Death fourhours
\end{tabular} dentally with knife. learful hremorrhage. haustion. after from shock Iarge ressels on surface. 'Tumour enil. cleated, uterus contractinar ufterwards. Edges of wound tied. Portion right side of uterus hypertrophied or fibroid. of uterus hypertrophied or fibroill. both ovaries removed.

for three days.
from poisoniugs Operated upon as for ovarintomy. No Shock. important adhesions. Right overy at. tacher to tumour and removed. Jeft con. nected to uterus.

Fibrocystic. 


\section{TABLE III-continued.}

\begin{tabular}{|c|c|c|c|c|c|c|}
\hline No. & $\begin{array}{c}\text { Operator and } \\
\text { Reference. }\end{array}$ & Age & Previous and General History. & Steps of the Operation. & After Progress. & Final Result. \\
\hline 26 & $\begin{array}{c}\text { Mr. Brown. } \\
\text { Communicated } \\
\text { Lond. Surg. } \\
\text { Home. }\end{array}$ & 45 & $\begin{array}{l}\text { Single. Admitted May } 6,1860 . \\
\text { Health good up to last } \$ \text { or } 4 \text { yrs., } \\
\text { when she had faintness and epis- } \\
\text { taxis. Regular up to Oct. last. Nine } \\
\text { years ago disc. small tum'r r. side } \\
\text { of abd.; this did not inc. till } 3 \text { or } 4 \\
\text { years ago. Had grown rapidly last } \\
6 \text { months. Had pneumonis } 10 \text { yrs. } \\
\text { back. Last March had erysipelas. } \\
\text { Examination: Small ovarian tum. } \\
\text { also a solid mass above pubis like } \\
\text { an enlarged uterus. Sound only } \\
\text { gets within the os. Hymen perfect. } \\
\text { Lungs sound. Heart healthy, but } \\
\text { weak. Fibrocystic. }\end{array}$ & $\begin{array}{l}\text { Onerated May 15. In dissecting as far as } \\
\text { peritoneum, the cyst found to be so aù- } \\
\text { herent that, in endeavouring to break it } \\
\text { down it was ruptured and three or four } \\
\text { pints of fluid escaped. A firm fibrous } \\
\text { mass was then discovered bound down by } \\
\text { such firm adhesions that it could not be } \\
\text { moved. Therefore a piece of cyst on each } \\
\text { side was cut off, and the wound closed as } \\
\text { usual. }\end{array}$ & $\begin{array}{l}\text { Went on pretty } \\
\text { well till the } 26 \mathrm{th}, \\
\text { when fluctuation } \\
\text { becsme distinct } \\
\text { over abdomen, } \\
\text { w. erysipelatous } \\
\text { redness. Pulse } \\
\text { quick. Tongue } \\
\text { dry and foul. } \\
\text { 31st, began to } \\
\text { sink. }\end{array}$ & $\begin{array}{l}\text { Died June } 8 \text {, } \\
\text { of phlegmonous } \\
\text { erysipelas of left } \\
\text { leg. The saine } \\
\text { epidemic pre- } \\
\text { vailed in the } \\
\text { hospital. }\end{array}$ \\
\hline 27 & $\mid \begin{array}{c}\text { Mr. Fleteber. } \\
\text { Communicated } \\
\text { by Dr. } \\
\text { Grimsdale. }\end{array}$ & 40 & $\begin{array}{l}\text { Widow with } 5 \text { children. Three mis- } \\
\text { carriages. Ceased to menstruate } \\
6 \text { months ago. Tum' frit noticed } \\
13 \text { months ago on right side. Cir- } \\
\text { cumference of abdomen, 3ri in. } \\
\text { Tum'r moveable, contuining large } \\
\text { masses of \&olid matter. After oper- } \\
\text { ation, tumour found to weigh } 14 \frac{1}{2} \\
\text { lbs. Struct. identical with uterine } \\
\text { fibroid tum'rs, studded with cysts } \\
\text { of rarious sizes. Extrauterine. } \\
\text { Fibrocystic disease. }\end{array}$ & $\begin{array}{l}\text { Opeíated May 14, 1862. Incision, } 5 \text { in., } \\
\text { from } 2 \text { in. below umbil Anter. surface of } \\
\text { tumour closely adherent, \& } 3 \text { in. of edge } \\
\text { of omentum to tumour on right side. Tro- } \\
\text { car passed into tumour, scarcely any fluid } \\
\text { crme. Incision extended to } 2 \text { in. above } \\
\text { umbilicus. Many cysts ruptured or punct. } \\
\text { Tumour found to spring from back of ute- } \\
\text { rus below the fundus and to left of median } \\
\text { line. Its base (it conld hardly be called a } \\
\text { pedicle) was about } 1 \frac{1}{2} \text { in. diameter. This } \\
\text { was cut with écraseur in about } 20 \text { minutes. } \\
\text { Two ligatures of iron wire put on vessels } \\
\text { which bled on the cut uterine surface. } \\
\text { Ligat. cut short and left. Wound closed } \\
\text { by pins and fig.-of-8 sutures, and superfi- } \\
\text { cial sutures. Abdomen not sponged out. }\end{array}$ & $\begin{array}{l}\text { Vomited once or } \\
\text { twice the vight } \\
\text { and day after } \\
\text { operation; com- } \\
\text { plained of pains } \\
\text { like afterpains } \\
\text { in the uterus. } \\
\text { These relieved } \\
\text { by gruel, } 1 \frac{1}{2} \text { oz. } \\
\text { tinct. opii } 20 \\
\text { minims. Had } \\
\text { verylittle stimu- } \\
\text { lant. }\end{array}$ & $\begin{array}{l}\text { Recovered well. } \\
\text { Readmitted into } \\
\text { hospital a few } \\
\text { months since, } \\
\text { with eczema } \\
\text { otherwise well } \\
\text { and fat. }\end{array}$ \\
\hline 23 & $\begin{array}{l}\text { Mr. Hakes. } \\
\text { Brit. Med. } \\
\text { Journal, } \\
\text { Feb. } 28,1863 .\end{array}$ & 42 & $\begin{array}{l}\text { Married. Had } 2 \text { children, youngest } \\
\text { 15. Enlargement first noticed } 18 \\
\text { months ago. Then appear'd to have } \\
\text { abd. full of ascitic fluid, \& a harder } \\
\text { tumour below. Tapped ; several } \\
\text { pts. of amber fluid liberated, when } \\
\text { an irreg. nodulated tumour was } \\
\text { felt. Uterus moveable, but less so } \\
\text { than usual. 9 months ago, tapped } \\
\text { again, and wheu about 1 pt. of fluid } \\
\text { had come away, cannula came agst. } \\
\text { a hard tumour. Ten days aft. again } \\
\text { tapped high up above umbilicus, } \\
\text { and a large quantity of fluid came } \\
\text { away. Cysts and solid tum'r rem. } \\
\text { behind. Diagnosis made ovarian } \\
\text { dropsy. Extrauterine, fibrocystic. }\end{array}$ & $\begin{array}{l}\text { Operated Jan. } 29,1863 \text {. Incision usual } \\
\text { length, to an in. above umbilicus. Tumour } \\
\text { found adherent to omentum \& intestines. } \\
\text { Connected by a small band, with scarcely } \\
\text { a pedicle. This was transfixed by double } \\
\text { ligature, and both sides tied, a third wire } \\
\text { encircling the whole. Tumour was found } \\
\text { to be made up of cysts of narrow sizes } \\
\text { with thin walls. One or two, however, } \\
\text { with solid bloody matter. Right ovary } \\
\text { was felt to be somewhat enlarged. Some } \\
\text { fluid escaped in abdomen, which was } \\
\text { sponged out. }\end{array}$ & $\begin{array}{l}\text { For several hrs. } \\
\text { appeared to } \\
\text { be doing well. } \\
\text { Still never ral. } \\
\text { lied. }\end{array}$ & $\begin{array}{l}\text { Died } 33 \text { hours } \\
\text { after operation, } \\
\text { from shock. } \\
P . M \text {. No inflam- } \\
\text { matory action; } \\
\text { wnd. firmly hld. } \\
\text { Both ovaries dis. } \\
\text { each cont. } 2 \text { or } 3 \\
\text { small tumours. } \\
\text { Small polypus } \\
\text { found on cervix } \\
\text { uteri, and } 1 \text { or } 2 \\
\text { tibroids imbed'd } \\
\text { in uterine wall. }\end{array}$ \\
\hline 29 & $\begin{array}{c}\text { Mr. Cadge, } \\
\text { of Norwich. } \\
\text { Communicated } \\
1863 .\end{array}$ & 30 & $\begin{array}{l}\text { Single. Health good. Five years' } \\
\text { growth. Generally regular, at one } \\
\text { time there was slight sanguineous } \\
\text { drain, never hæmorrhage. Tumour } \\
\text { was in abdomen, size of } 8 \text { months } \\
\text { pregnancy. Diagnosed at Norwich } \\
\text { and in London to be ovarian. } \\
\text { Parietal. }\end{array}$ & $\begin{array}{l}\text { When abdomen was opened, tumour rolled } \\
\text { out. Tapped ; found solid. Uterine wall } \\
\text { now peeled oft and tumour enucleated. } \\
3 \text { or } 4 \text { large vessels tied, and then redund. } \\
\text { uterine flaps.wh.had cov.the growth, r'mov. } \\
\text { As the bleeding was, however, very free, } \\
\text { to check this, \& also remove any smaller } \\
\text { tumours, wh. might \& probably did exist, } \\
\text { a strong double ligature was passed thro' } \\
\text { cervix, and lateral halves tied, and whole } \\
\text { uterus and ovaries removed. There was } \\
\text { no more bleeding. }\end{array}$ & $\cdots$ & $\begin{array}{l}\text { Died of shock } \\
\text { apparently, } 36 \text {. } \\
\text { hours after oper- } \\
\text { ation. }\end{array}$ \\
\hline 30 & $\begin{array}{l}\text { Dr. E. R. } \\
\text { Peaslee. } \\
\text { America. } \\
\text { Am Journ. of } \\
\text { Med. Sci. } \\
\text { 1855, p. } 393 \text {. }\end{array}$ & 35 & $\begin{array}{l}\text { No account of duration. Tumour } \\
\text { wns found to be a uterine fibroid, } \\
5 \frac{1}{2} \text { in. long, } 4 \text { broad, and } 3 \text { thick. } \\
\text { Extrauterine. }\end{array}$ & $\begin{array}{l}\text { Operated Sept. } 21,1833 \text {. Incision } 6 \text { in. } \\
\text { Tumour taken for fluctuating one; punc- } \\
\text { tured with trocar. Great hæmorr. A ligat. } \\
\text { was then applied round neck of tumour \& } \\
\text { whole body above the ligature excised. }\end{array}$ & $\cdots$ & $\begin{array}{l}\text { Death on } 4 \text { th } \\
\text { day, from peri - } \\
\text { tonitis and gan- } \\
\text { grene of intest. }\end{array}$ \\
\hline $\mathbf{s 1}$ & $\begin{array}{l}\text { Dr. Kœberle. } \\
\text { Med. Gaz. of } \\
\text { Strasbourg, } \\
\text { No. } 10,1863 . \\
\text { Presse Médi- } \\
\text { cale Belge, } \\
\text { Nov. } 1868 .\end{array}$ & 30 & $\begin{array}{l}\text { Married } 6 \text { years. Nervous. Began } \\
\text { to menstruate at } 15 \text {. No children. } \\
\text { Miscarriage } 5 \text { yrs. ago at } 3 \text { months. } \\
\text { Then noticed hard tumour left side } \\
\text { of pelvic region. This was made } \\
\text { out tc be a uterine fibroid. It grew } \\
\text { without disurbance of gen. system. } \\
\text { 3 years ago, believed to be a mixed } \\
\text { tum'r. Arsenical pills and indized } \\
\text { iron prod. no effect. Micturition } \\
\text { difficult. Menorrhagia w. sickness } \\
\text { at the epochs. In present state, } \\
\text { tumour believed to be ovarian or } \\
\text { fibroid of uterus. }\end{array}$ & $\begin{array}{l}\text { Operat. April } 20,1863 \text {. Incision } 3 \frac{1}{2} \text { centim. } \\
\text { above umbilicus to } 3 \text { above jubbes. Little } \\
\text { bleeding. 'Tumour free from adhesions } \\
\text { superiorly, but connected w. epiploon by } \\
3 \text { arteries as large as radial. Ligat. \& cut. } \\
\text { Tumour found to be solid. Incis.enlarged. } \\
\text { Pedunculated tumour came out, and was } \\
\text { secured by the chrin of an écraseur. In- } \\
\text { testines were now moved aside. Uterus } \\
\text { found large, contain'g a fibroid size of nut. } \\
\text { Right ovary healthy; left large, w. Graa- } \\
\text { fan vesicle on it ready to burst. Cervix } \\
\text { transfixed, double iron ligature applied } \\
\text { including broad ligaments and ovaries. } \\
\text { The whole part above the ligatures cut. } \\
\text { Cavity of abdomen cleaned out. Ends of } \\
\text { cut portion touched with perchloride of } \\
\text { iron. Other vessels tied. }\end{array}$ & $\begin{array}{l}\text { Very fair pulse, } \\
\text { never rose above } \\
\text { 105. Suff'd from } \\
\text { cough. Ligature } \\
\text { came away on } \\
\text { 13th or 14th } \\
\text { day. }\end{array}$ & $\begin{array}{l}\text { Recovery com- } \\
\text { plete } 30 \text { th day. }\end{array}$ \\
\hline కి2 & $\begin{array}{l}\text { Kœberle. } \\
\text { 2nd case. }\end{array}$ & • & $\begin{array}{l}\text { Ascitic for a long time, obliging } \\
\text { punct. by the trocar every } 5 \text { days, } \\
\text { to remove } 12 \text { or } 13 \text { pints of serum. } \\
\text { Operation one of urgency. } \\
\text { Pedictlated Extrauterine. }\end{array}$ & $\begin{array}{l}\text { Operated December } 5 \text {, i863. Adhesions } \\
\text { very extensive and highly vascular. } \\
\text { Twenty ligatures applied both to arteries } \\
\text { aud veins. }\end{array}$ & .. & $\begin{array}{l}\text { Died of peritoni- } \\
\text { tis as a result of } \\
\text { the recurrence of } \\
\text { ascites. }\end{array}$ \\
\hline
\end{tabular}




\section{TABIE III-continued.}

\begin{tabular}{|c|c|c|c|c|c|c|}
\hline No. & $\begin{array}{l}\text { Cperator and } \\
\text { Locality. }\end{array}$ & Age & Previous and General History. & Steps of the Operation. & After Progress. & Final Result. \\
\hline 33 & $\begin{array}{c}\text { Kœberle. } \\
\text { Communicated }\end{array}$ & 24 & $\begin{array}{l}\text { Tumour weigbing } 33 \text { kilog. } 5 \text { yrs. } \\
\text { ago, observed abd. was enlarging. } \\
\text { First came a suspicion of pregn'cy, } \\
\text { then of an ovarian tumour, tluct. } \\
\text { being very evid. 'Tapped } 7 \text { times } \\
\text { without effet. In } 1863 \text {, belly enorm. } \\
\text { swelling ext. to scaphoid cartilage. } \\
\text { Dyspnoes urgent, face cyanosed, } \\
\text { decubitus lateral. Fluctuation was } \\
\text { so evident, she was again tapped, } \\
\text { blood only exuding. Walls of abd. } \\
\text { slightly edemstous. } \\
\text { Extraiterine, Pedunculated. }\end{array}$ & $\begin{array}{l}\text { Operated March } 4,1863 \text {. Incis. } 55 \text { centim. } \\
\text { Large fibroid exposed, whieh at the least } \\
\text { succussion shook like jelly, adherent to } \\
\text { epiploon by large tortuous vessels. These } \\
\text { tied ard cut on both sides. Ovaries healthy. } \\
\text { Metallic ligature put around pedicle, wh. } \\
\text { was about size of a fist when cut. At least } \\
2 \text { litres of blood came away from cut end. } \\
\text { Parts now sponged. Iarge bleeding veins } \\
\text { tied. } \Lambda \text { small superficial part of adherent } \\
\text { liver having been removed, exuded bile } \\
\text { and blood. This was arrested b! the per- } \\
\text { chlorida of iron. Operation lnsted } 2.1 \text { hrs. } \\
\text { A small portion of air retained in abdo- } \\
\text { men. Wound closed. }\end{array}$ & $\begin{array}{l}\text { For two first } \\
\text { days did pretty } \\
\text { well; 3rd, vio- } \\
\text { lent sickness, } \\
\text { and death from } \\
\text { exhaustion aud } \\
\text { dyspnca. }\end{array}$ & $\begin{array}{l}\text { Died Murch 8. } \\
P . M . \text { Air ab- } \\
\text { sorbed. Wound } \\
\text { two-thirds heal'd } \\
\text { Some serum in- } \\
\text { feriorly from } \\
\text { œdematous walls } \\
\text { T'umour entirely } \\
\text { disappeared. No } \\
\text { phlebitis or false } \\
\text { membrane. Two } \\
\text { litres of sero- } \\
\text { purulent fluid } \\
\text { in right pleura. } \\
\text { Death thus due } \\
\text { to pleurisy. }\end{array}$ \\
\hline
\end{tabular}

recovered was one in which it was stated that all the loutside of the true pelvis, where they could be easily uterus except the cervix was removed. All in and got at and removed.

about the diseased organ was removed.

3. The last category of cases, however, appears to be most interesting. In all, they amount to nine, with four recoveries. One death here appears to have resulted from hæmorrhage, the ligature not having been sufficiently secured; and one death was purely accidental.

This last, one of Dr. Clay's, had all but recovered; the wound had healed; the ligatures had come away; and she was progressing rapidly towards convalescence, when she fell heavily to the ground when the bed was making. The shock to her system appears to have determined inflammatory complications, of which she died.

These last two cases should, therefore, fairly be excluded. 'This would give seven cases, and four recoveries-more than half. In all these, the ovaries (with the exception of one case, one of Mr. Wells, in which one ovary only was removed) were extirpated, as well as the entire uterus. And, in order that this should be done, the uterus must have been high up and well without the true pelvis.

It is obvious, however, on more closely reviewing these cases in which gastrotomy has been performed successfully, that it is precisely in those cases where the tumour was high up in the false pelvis, that the success has been greatest. Secondly, in those where the ovaries were removed, it is this same contingency which contributed to their ready extirpation also ; and, thirdly, it was also in these cases where the whole diseased mass was capable of removal.

The first contingency is the reverse of what we observed in cases of enucleation per vaginam. If such tumours are to be removed by gastrotomy at all, it is a favourable position. Secondly, a very little reflection will shew that it would be impossible, except in a case where the uterus and ovaries were high up in the false pelvis, to remove them en masse. For, if we look for a moment to the large vessels in immediate contiguity, the broad ligaments which have to be cut through, the position of the bladder, ureters, spermatic artery, the objections to the operation appear very great, almost insurmountable, if there be any extensive adhesions; and yet the only four cases on record, if we exclude extrauterine tumours, in which recovery has followed, have been the cases in which Drs. Clay, Burnham, Koberle, and Boyd removed both uterus and ovaries. And this could not have been effected, unless, as before urged, the uterus and ovaries had been well drawn up
At post mortem examinations, with the abdominal walls opened low down, even to the front of the bladder, and when all the intestines are moved out of the way, even when the rectum is included, anybody who has tried it must have experienced how great is the difficulty to separate away the contents of the true pelvis. But, admitting it were possible, how could the arteries cut across be secured? and would it be possible to remove such a mass without wounding the large veins in this cavity?

\section{. [To be continued. $]$}

\section{Cransactions of âdramethes.}

\section{BENGAL BRA N CH.}

ADDRESS IN MEDICINE : THE PRESENT STATE OF THF MEDICAL PROFESSION IN BENGAL.

By S. Goodeve Chuckerbutty, M.D.

[Concluded from page 88.7

There are now in the Calcutta Medical College three classes of students : the first created, or the English class; the next created, or the military class; and the third created, or the Bengali class. Into each of these, young men of all castes, creeds, and colours, of all nations and countries, are freely admissible; and from them have annually gone forth into the world large numbers of physicians and sur: geons. Connected with this College, there is now a magnificent hospital, in the wards and dispensaries of which relief is afforded to a vast number of patients, in every department of the profession; an extensive museum of anatomical, pathological, zoological, mineralogical, and pharmacentical specimens; a fine chemical laburatory; a good library; and vast dissecting accommodation. Following the example of Calcutta, similar medical Echools have been formed also at Bombay, Madras, Hyderabad, Agra, and Lahore. Thus there are now six well-founded medical colleges in the country, three of which belong to our own Presidency; and numbers of good hospitals. In all these, a vast number of students are learning together, in honourable rivalry, every branch of medical knowledge imported from the best schools of Europe. We have side by side English medical schools and vernacular medical schools, English medical teachers and vernacular medical teachers, English medical practitioners and vernacular medical practitioners. Year after year, a fresh crowd of medical students are 